\title{
Susceptibility of the Stem Pull Area of Mechanically Harvested Apples to Blue Mold Decay and Its Control with a Biocontrol Agent
}

\author{
W. J. Janisiewicz and D. L. Peterson, USDA ARS, Appalachian Fruit Research Station, Kearneysville, WV 25430
}

\begin{abstract}
Janisiewicz, W. J., and Peterson, D. L. 2004. Susceptibility of the stem pull area of mechanically harvested apples to blue mold decay and its control with a biocontrol agent. Plant Dis. 88:662664 .

A new harvester, which uses a rapid displacement actuator on the main scaffolds to remove apples from trees with narrow-inclined trellises, has shown good potential. With this technique, stem loss (stempulls) during harvest ranges from 20 to 57\%, depending on the cultivar. This can create a potential point of entry for pathogens. We evaluated the susceptibility of the stem cavity area, with and without stems, to blue mold decay (Penicillium expansum) on three cultivars of mechanically harvested apples, and tested the effectiveness of the antagonist Pseudomonas syringae (used in BioSave 110) in controlling decay. Fruit with stempulls were more susceptible to blue mold decay than fruit with stems. On fruit with stempulls inoculated with $P$. expansum and stored for 2 months at $1^{\circ} \mathrm{C}$, decay incidence was $0 \%$ on 'Pink Lady', $8.3 \%$ on 'Ace Spur Delicious', and $41 \%$ on 'Empire'. On fruit with stems, there was no decay on all three cultivars. P. syringae reduced decay on 'Empire' with stempulls to $3.3 \%$, and no decay occurred on the other two cultivars. Similar trends were observed on fruit stored at $22^{\circ} \mathrm{C}$ for 14 days, but the incidence of decay was higher, and only 'Pink Lady' had no decay on the antagonist-treated fruit. Although mechanical harvesting can predispose the stem cavity to decay in some cultivars, this problem can be alleviated using biological control without resorting to the use of synthetic pesticides.
\end{abstract}

Additional keywords: Malus $\times$ domestica, pome fruits, postharvest
Earlier attempts to harvest apples mechanically by mass removal techniques (shake/catch) have not been successful due to excessive fruit damage $(2,7)$. A new harvester, which uses a rapid displacement actuator (RDA) on the main scaffolds to remove apples from trees with narrow-inclined trellises, has shown good potential (8). With this technique, USDA Extra Fancy packout of eight apple cultivars ranged from 59 to $84 \%$. Stem loss (stempulls) during harvest ranged from 20 to $57 \%$, depending on the cultivar. If a portion of apple skin is removed together with the stem, flesh tissue is exposed, creating a potential point of entry for pathogens. Thus, it is important to know to what extent this new harvesting technology will predispose apples to postharvest decay. The objective of this study stem cavity area of different apple cultivars with and without stems to infection by

E-mail: wjanisie@afrs.ars.usda.gov

Accepted for publication 4 February 2004

Publication no. D-2004-0402-01R

This article is in the public domain and not copyrightable. It may be freely reprinted with customary crediting of the source. The American Phytopathological Society, 2004. was to determine the susceptibility of the

Corresponding author: W. J. Janisiewicz
Penicillium expansum, and the ability of new decay-control technology using the biocontrol agent Pseudomonas syringae (ESC-11) (4) to control this decay.

\section{MATERIALS AND METHODS}

Three apple cultivars were used in the studies. The trees were planted in 1994 ('Empire'/M9) and 1997 ('Ace Spur Delicious'/M7 and 'Pink Lady'/M9). They were trained to a Y-trellis with a vertical post $70 \mathrm{~cm}$ in height and arms $2 \mathrm{~m}$ each set at $52.4^{\circ}$ from the horizontal with three leaders equally spaced $40 \mathrm{~cm}$ on each side of the trellis arms. The rows were $4.9 \mathrm{~m}$ apart and trees were spaced every $1.2 \mathrm{~m}$ in the row.

Fruit were harvested when the majority reached a commercially acceptable stage of maturity based on starch index rating, soluble solids concentration, and flesh firmness (1). The harvester was described by Peterson and Wolford (8) (Fig. 1). It utilizes the RDA for fruit removal, has soft catching conveyors to collect the fruit, and has an automatic bin filler. After harvest, the apples were manually separated into two categories, with and without stems, and placed on fruitpack trays.

The $P$. expansum (MD-8) isolate used is very aggressive and was previously isolated from a decayed apple in storage and used in previous biocontrol tests $(4,6)$. The fungus was maintained on potato dextrose agar (PDA), and continued virulence was

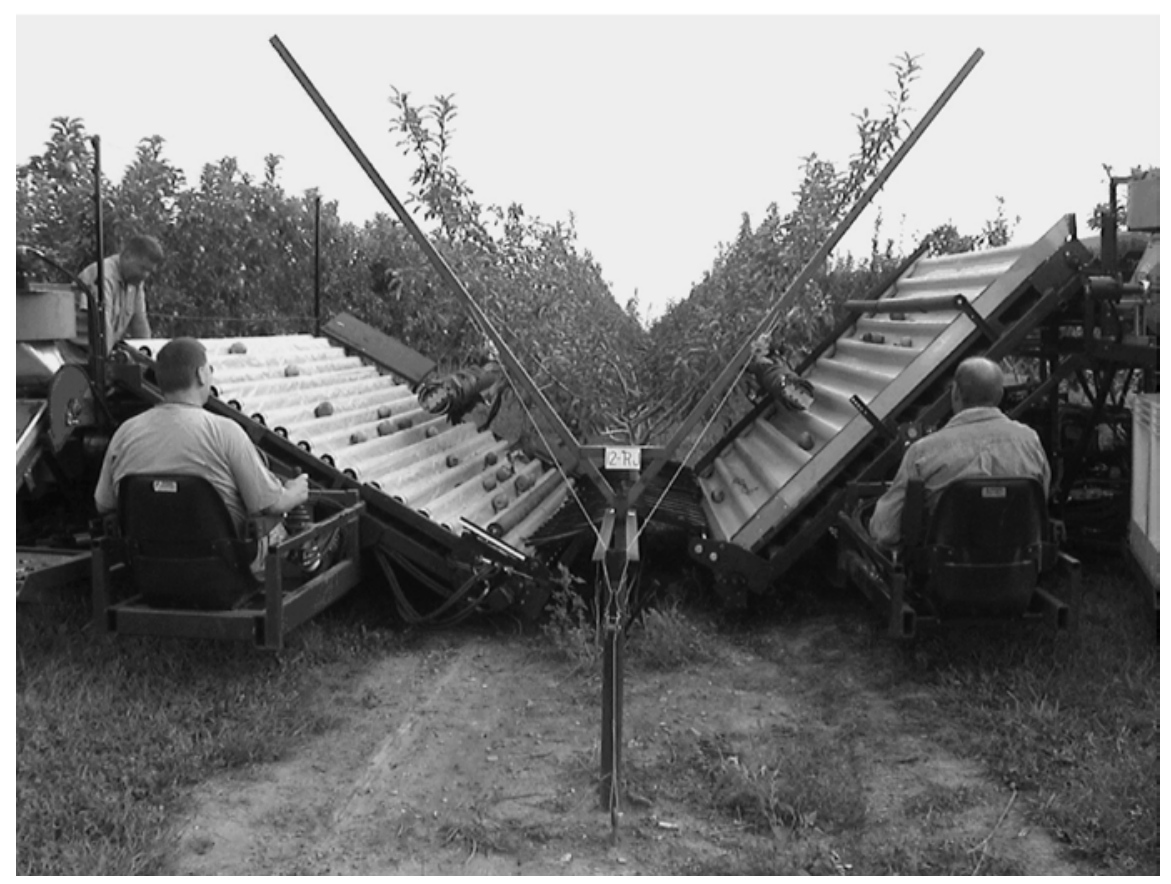

Fig. 1. Two-side mechanical apple harvester used in the study. On each unit, the operator uses a joystick to position and engage the rapid displacement actuator (RDA) on main scaffolds to remove fruit. Catching conveyers intercept falling fruit without damage and elevate fruit to a collecting conveyor on the top, which transports fruit to a bin filler. 
assured by periodic passage through apple. Concentrated conidial suspensions were prepared from 10-day-old cultures as previously described (6). The concentrated conidia were diluted in water or added to the antagonist suspension to achieve final concentrations of $5 \times 10^{3}, 5 \times 10^{4}$, and $5 \times$ $10^{5}$ conidia per $\mathrm{ml}$ in 2001 , and $5 \times 10^{4}$ and $5 \times 10^{5}$ conidia per $\mathrm{ml}$ in 2002 and 2003.

The Pseudomonas syringae strain, L-5966 , used in these studies is the bacterium that has been used in BioSave 11 and 110 commercial products (Village Farms L. P. Bio-Save Division, Longwood, FL) for control of postharvest fruit decays $(4,6)$. The bacterium was grown in $50 \mathrm{ml}$ of nutrient yeast dextrose broth (NYDB) medium in 250-ml Erlenmeyer flasks on a rotary shaker at $150 \mathrm{rpm}$ at $26^{\circ} \mathrm{C}$. Following incubation for $24 \mathrm{~h}$, the cells were harvested by centrifugation at 7,000 $\times g$ for $10 \mathrm{~min}$, resuspended in sterile water, and the concentration adjusted to $\sim 3 \times 10^{8}$ $\mathrm{CFU} / \mathrm{ml}$ (50\% transmission) with a spectrophotometer at $420 \mathrm{~nm}$.

Fruit were inoculated with the pathogen alone or with the combined pathogen-antagonist suspensions from late August through early November, depending on cultivar. In the 2001 study, only 'Empire' and 'Pink Lady' fruit were inoculated with the pathogen, and in the second and third years, 'Empire', 'Pink Lady', and 'Ace Spur Delicious' were inoculated with either the pathogen or the pathogen-antagonist suspensions. Only the two highest concentrations of the pathogen were used in the second- and third-year experiments. Stem or stemless fruit were inoculated at the stem end cavity with $25 \mu \mathrm{l}$ of the pathogen or the pathogen-antagonist suspension. In 2002 and 2003, 45 to 60 min after inoculation, one set of fruit was placed in cardboard fruit boxes with perforated polyethylene liners and placed in cold storage at $1 \pm$ $1^{\circ} \mathrm{C}$. These fruit were evaluated for the presence or absence of decay in the stem end cavity after 2 months of storage. Another set was stored at $22^{\circ} \mathrm{C}$ for 14 days. The incidence of decay was reported at the end of the storage period. There were 20 fruit per replicate and three replicates per treatment for fruit stored at $1{ }^{\circ} \mathrm{C}$ and at $22^{\circ} \mathrm{C}$.

Data analysis. Results from the 2002 and 2003 experiments were analyzed separately using the general linear model (GLM) of the Statistical Analysis System (SAS/STAT User's Guide, ver. 6, 4th ed. SAS Institute, Cary, NC), with cultivar, stem, and antagonist as treatment variables and incidence of decay as the response variable. A Waller-Duncan multiple range test $(k$-ratio $=100)$ was conducted on the fruit decay data for individual treatments and all cultivars, and on different treatments for each cultivar.

\section{RESULTS}

In the 2001 studies, we observed large differences between cultivars in the susceptibility of the stem cavity area to blue mold decay after artificial inoculation with Penicillium expansum. On apples with stempulls inoculated with the highest concentration of the pathogen $\left(5 \times 10^{5}\right.$ conidia per $\mathrm{ml}$ ), the mean incidence of decay was $11.1 \%$ on 'Pink Lady' and $86.7 \%$ on 'Empire'; while on apples with stems, it was only $8.3 \%$ on 'Empire' and $0 \%$ on 'Pink Lady' after 2 weeks at $24^{\circ} \mathrm{C}$ (Fig. 2). Also, on fruit with stempulls, decay increased as the concentration of the pathogen increased, while this increase was not observed on fruit with stems.

Analysis of the data from 2002 and 2003 studies revealed that cultivar, presence or absence of stem, and antagonist treatments were all highly significant $(P<$ $0.001)$ at both storage temperatures. Overall, in both years, the most susceptible cultivar was 'Empire', then 'Ace Spur Del.', and then 'Pink Lady', except in 2003 at $1^{\circ} \mathrm{C}$, when there was no significant difference between 'Ace Spur Del.' and 'Pink Lady'. There was a significant interaction between cultivar and stem treatments. More decay developed on fruit with stempulls on 'Empire' and 'Ace Spur Del.', but not on 'Pink Lady', at both temperatures in 2002 and 2003.

Little decay developed on fruit inoculated with $5 \times 10^{4}$ conidia of $P$. expansum per $\mathrm{ml}$ after 2 months in storage at $1^{\circ} \mathrm{C}$. Thus, only results from inoculation with 5 $\times 10^{5}$ conidia per $\mathrm{ml}$ are reported (Table 1 ). After 2 months of cold storage in the 2002 experiment, on fruit with stempulls, decay developed on $41 \%$ of 'Empire', $8.3 \%$ of 'Ace Spur Del.', and no decay developed on 'Pink Lady'. Application of the antagonist reduced decay to $3.3 \%$ on 'Empire', and no decay developed on the other two cultivars. On apples with stems inoculated with the pathogen alone, little or no decay developed. Similarly, there was no decay on apples with stems inoculated with a suspension containing both pathogen and antagonist. Incubating apples for an additional 7 days at $22^{\circ} \mathrm{C}$ had almost no effect on the increase of decay. In 2003 again the most susceptible cultivar was 'Empire', where the antagonist treatment reduced decay on fruit with stempulls from 23.3 to

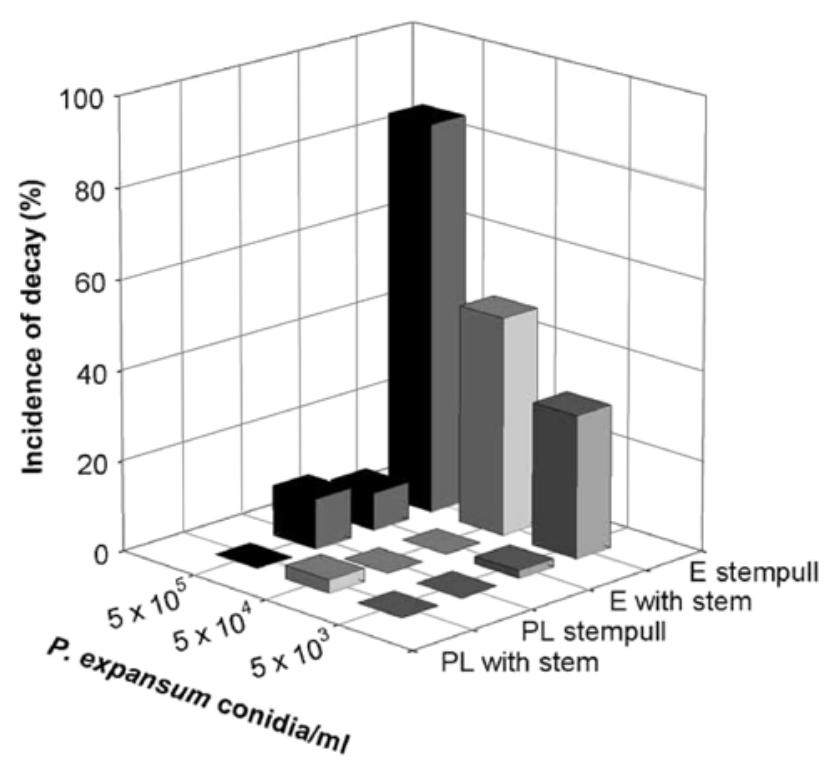

Fig. 2. Incidence of blue mold decay in 2001 on mechanically harvested apple fruit of cultivars Empire (E) and Pink Lady (PL) with and without stems (stempulls), inoculated in the stem cavity area with various concentrations of Penicillium expansum, and incubated at $24^{\circ} \mathrm{C}$ for 14 days. For 'Empire', $\mathrm{LSD}=12.2$, and for 'Pink Lady', $\mathrm{LSD}=7.1, P=0.05$.

Table 1. Development of blue mold in the stem cavity area in 2002 on mechanically harvested apple fruit with and without stems (stempulls) after inoculation with Penicillium expansum alone or in combination with the antagonist Pseudomonas syringae (ESC-11) ${ }^{\mathrm{x}}$

\begin{tabular}{lcccc}
\hline & \multicolumn{4}{c}{ Incidence of decay (\%) } \\
\cline { 2 - 5 } Cultivar & Stempulls & Stempulls/antagonist & Stem & Stem/antagonist \\
\hline Empire & $41.0 \mathrm{~A}^{\mathrm{y}} \mathrm{a}^{\mathrm{z}}$ & $3.3 \mathrm{Ab}$ & $0.0 \mathrm{Ab}$ & $0.0 \mathrm{Ab}$ \\
Ace Spur Del. & $8.3 \mathrm{Ba}$ & $0.0 \mathrm{Ab}$ & $0.0 \mathrm{Ab}$ & $1.7 \mathrm{Ab}$ \\
Pink Lady & $0.0 \mathrm{Ca}$ & $0.0 \mathrm{Aa}$ & $0.0 \mathrm{Aa}$ & $0.0 \mathrm{Aa}$ \\
\hline
\end{tabular}

${ }^{\mathrm{x}}$ Fruit were stored at $1^{\circ} \mathrm{C}$ for 2 months.

${ }^{\mathrm{y}}$ Means within columns with different uppercase letters are significantly different according to the Waller-Duncan test $k$-ratio $=100$.

${ }^{\mathrm{z}}$ Means within rows with different lowercase letters are significantly different according to the Waller-Duncan test $k$-ratio $=100$. 
Table 2. Development of blue mold in the stem cavity area in 2002 on mechanically harvested apple fruit with and without stems (stempulls) after inoculation with Penicillium expansum alone or in combination with the antagonist Pseudomonas syringae (ESC-11) ${ }^{\mathrm{x}}$

\begin{tabular}{lcccc}
\hline & \multicolumn{4}{c}{ Incidence of decay (\%) } \\
\cline { 2 - 5 } Cultivar & Stempulls & Stempulls/antagonist & Stem & Stem/antagonist \\
\hline Empire & $86.7 \mathrm{~A}^{\mathrm{y}} \mathrm{a}^{\mathrm{z}}$ & $66.7 \mathrm{Ab}$ & $5.0 \mathrm{Ac}$ & $3.4 \mathrm{Ac}$ \\
Ace Spur Del. & $41.7 \mathrm{Ba}$ & $11.7 \mathrm{Bb}$ & $1.7 \mathrm{Ac}$ & $1.7 \mathrm{Ac}$ \\
Pink Lady & $5.0 \mathrm{Ca}$ & $0.0 \mathrm{Ca}$ & $1.7 \mathrm{Aa}$ & $0.0 \mathrm{Aa}$ \\
\hline
\end{tabular}

${ }^{\mathrm{x}}$ Fruit were stored at $22^{\circ} \mathrm{C}$ for 14 days.

y Means within columns with different uppercase letters are significantly different according to the Waller-Duncan test $k$-ratio $=100$.

${ }^{\mathrm{z}}$ Means within rows with different lowercase letters are significantly different according to the Waller-Duncan test $k$-ratio $=100$.

$1.7 \%$, followed by 'Ace Spur Del.' with a reduction from 5.0 to $0 \%$, and 'Pink Lady', for which no decay developed on fruit treated with the pathogen or pathogenantagonist combination.

On the set of apples with stempulls that was stored at $22^{\circ} \mathrm{C}$ for 7 days, the most decay developed on 'Empire' and 'Ace Spur Del.', mainly at the higher pathogen concentration (data not shown). Since little or no decay developed on 'Pink Lady', we extended the storage time to 14 days in the 2002 and 2003 experiments. This caused many fruit to become overmature; nevertheless, the decay incidence increased further on fruits with stempulls, but there was little or no decay on apples with stems (Table 2). Addition of the antagonist significantly reduced decay on 'Empire' and 'Ace Spur Del.' Although these reductions were significant, the amount of decay was still relatively high. Similar results were obtained in 2003, but overall lesions were smaller than in 2002.

\section{DISCUSSION}

Our study revealed that stempulls predispose some cultivars to decay, while others remain unaffected. This was best illustrated on 'Empire', since fruit with stempulls had a high incidence of decay, while 'Pink Lady' had little or no decay in all years of the study. In addition, the stem cavity area on fruit with stems was very resistant to decay in all cultivars. An increase in decay with increasing concentration of the pathogen on fruit with stempulls, but not on fruit with stems, further confirms that removing stems during mechanical harvest predisposes fruit to decay. Conidia of $P$. expansum may be present in the air and on fruit surfaces, but the major contamination of pome fruits that results in fruit decay occurs after harvest during drenching and handling fruit in water. In our experiments, we used pathogen concentrations that represented a worst-case scenario under commercial conditions, where conidia of the fungus accumulate with each fruit passing through the system (9).

Although decay development may suggest limited use of mechanical harvesting on some cultivars, treatment of the stempull fruit with the biocontrol agent greatly reduced or completely eliminated decay, even in the most severe case on 'Empire' stored at $1^{\circ} \mathrm{C}$. This indicates that the potential problem of fruit decay originating in the stem cavity of fruits with stempulls could be managed with the new technology $(4,5)$ without the additional use of synthetic fungicides. Antagonist treatment also reduced decay on other mechanically harvested cultivars in 2002 that developed significant decay on fruit with stempulls, such as 'Scarlet Spur Del.' and 'Sun Fuji' stored at $1{ }^{\circ} \mathrm{C}$, and on these and other cultivars such as 'Starkspur McIntosh', 'Crimson Gala', and 'Rubinstar Jonagold' stored at $22^{\circ} \mathrm{C}$ (unpublished data). At $1{ }^{\circ} \mathrm{C}$, in addition to 'Pink Lady', no decay developed on 'Rubinstar Jonagold' and 'Sun Crisp' with stempulls, and $5 \%$ or less decay developed on 'Starkspur McIntosh', 'Crimson Gala', 'Spur GoldBlush', and 'Starkspur Dixie Red' in the same studies. An addition of the antagonist often completely eliminated decay, but the differences were statistically not significant.

Efficacy of the biocontrol agent was lower on fruit stored at $22^{\circ} \mathrm{C}$ than at $1{ }^{\circ} \mathrm{C}$ because of the greater susceptibility to decay of the overmature fruit (incubation 14 days at $22^{\circ} \mathrm{C}$ ), which altered the dynamics of antagonist-pathogen interaction (10). This is substantiated by the fact that on the same fruit evaluated 7 days earlier, although less decay occurred overall, decay control by the antagonist was much more pronounced (data not shown). Many aspects of apple production technology are due for a significant change if U.S. growers want to remain competitive in the global market, where plentiful labor may be available and the use of synthetic fungicides after harvest is often prohibited (3). Both mechanical harvesting and biological control are developing technologies that address these problems, and our research demonstrated that they can work well together.

\section{ACKNOWLEDGMENTS}

We thank S. Wolford for help in harvesting and sorting fruit, and C. Walters for technical assistance in assessing fruit decay and summarizing the data.

\section{LITERATURE CITED}

1. Blanpied, G. D., and Silsby, K. L. 1992. Predicting harvest date windows for apples. Cornell Coop. Ext. Bull. 221

2. Brown, G. K., Marshall, D. E., Tennes, B. R. Booster, D. E., Chen, R. E., Garret, R. E., O'Brien, M., Studer, H. E., Kepner, R. A., Hedden, S. L., Hood, C. E., Lenker, D. H Millier, W. F., Rehkugler, G. E., Peterson, D. L., and Shaw, N. L. 1983. Status of harvest mechanization of horticultural crops. SP-3 ASAE, St. Joseph, MI.

3. Gullino, M. L., and Kuijpers, L. A. M. 1994. Social and political implications of managing plant diseases with restricted fungicides in Europe. Annu. Rev. Phytopathol. 32:559-579.

4. Janisiewicz, W. J., and Jeffers, S. N. 1997. Efficacy of commercial formulation of two biofungicides for control of blue mold and gray mold of apples in cold storage. Crop Prot. 16:629-633.

5. Janisiewicz, W. J., and Korsten, L. 2002. Biological control of postharvest diseases of fruits. Annu. Rev. Phytopathol. 40:411-441.

6. Janisiewicz, W. J., and Marchi, A. 1992. Control of storage rots on various pear cultivars with a saprophytic strain of Pseudomonas syringae. Plant Dis. 76:555-560.

7. Peterson, D. L., Miller, S. S., and Whitney, J. D. 1994. Harvesting semidwarf freestanding apple trees with an over-the-row mechanical harvester. J. Am. Hortic. Sci. 119:1114-1120.

8. Peterson, D. L., and Wolford, S. D. 2003. Fresh market tree fruit harvester. Part II: Apples. Appl. Engineering Agric. 19:545-548.

9. Spotts, R. A., and Cervantes, L. A. 1993 Filtration to remove spores of Penicillium expansum from water in pome fruit packinghouses. Tree Fruit Postharv. J. 4(1):16-18.

10. Usal, J., Garz, E., Si, J., and Vinas, I. 1998. Effect of pre-harvest factors and harvest time on biological control of Penicillium expansum on Golden Delicious apples. Int. Congr. Plant Pathol. 7th, London. Abstr. 5. 